\title{
Albumin to Ascites: Demonstration of a Direct Pathway Bypassing the Systemic Circulation
}

\author{
D. S. Zimmon, M. Oratz, R. Kessler, S. S. Schreiber, and \\ M. A. RothSCHID.D \\ From the Radioisotope Service and the Gastroenterology Section, Veterans \\ Administration Hospital, Department of Medicine, New York University \\ School of Medicine; and the Department of Biochemistry, New York \\ University College of Dentistry, New York 10010
}

A BSTRACT The transport of plasma albumin and newly made albumin into ascitic fluid was studied in eight patients with cirrhosis and ascites. The thoracic duct was cannulated in two patients and lymph collected over a period of $2 \mathrm{hr}$. Simultaneously albumin $-{ }^{181} \mathrm{I}$ and carbonate ${ }^{14} \mathrm{C}$ were injected intravenously. The albumin${ }^{131}$ I measured the transfer of plasma albumin into ascites and into thoracic duct lymph. The carbonate- ${ }^{14} \mathrm{C}$, by labeling newly formed albumin, permitted the estimation of the transfer of newly formed albumin into plasma, ascites, and lymph.

If the newly synthesized albumin entering ascites and thoracic duct lymph is delivered initially into the plasma, then the ratios of the albumin $-{ }^{11} \mathrm{C}$ and ${ }^{131} \mathrm{I}$ in ascites and lymph compared with the content of albumin $-{ }^{14} \mathrm{C}$ and ${ }^{-181} \mathrm{I}$ in plasma would be identical. However, if some newly formed albumin is delivered directly into ascites or lymph, the ratio for albumin $-{ }^{14} \mathrm{C}$ would be higher than that for albumin $-{ }^{181} \mathrm{I}$ in lymph or ascites.

The ratios of both labeled albumins found in ascites or lymph are expressed as per cent of the total plasma pool. In the eight patients studied $4.2-11.7 \%$ of the albumin $-{ }^{14} \mathrm{C}$ in plasma was found in ascites in $2 \mathrm{hr}$ whereas only $0.4-2.2 \%$ of plasma albumin ${ }^{181} I$ entered in this same period. In the two patients studied during thoracic duct lymph drainage 6.1 and $13.5 \%$ of newly made albumin ${ }^{14} \mathrm{C}$ appeared in lymph in $2 \mathrm{hr}$ whereas only 2.8 and $3.8 \%$ of plasma albumin- ${ }^{131} \mathrm{I}$ was found in the lymph.

In cirrhosis with ascites some newly formed albumin entered ascites and thoracic duct lymph by a direct pathway from the liver bypassing the systemic circulation.

This study was presented in part at the American Gastroenterological Association, Gastroenterology Research Group, Washington, D. C., May 1969.

Received for publication 23 April 1969 and in revised form 18 June 1969.

\section{INTRODUCTION}

The source of albumin in ascitic fluid has long been the subject of investigation (1). Albumin has been presumed to enter the ascitic fluid via lymphatics from the systemic circulation, from hepatic lymphatics, or by a route not previously demonstrated. While the liver is the sole source of serum albumin (2) the direct release of this albumin into the systemic circulation has only recently been documented $(3,4)$. The lymph draining a normal liver receives albumin mainly from plasma (4). Only a small amount of newly synthesized albumin passes directly into lymph. In the dog this situation persists even when significant hepatic venous obstruction exists (4). If these findings apply to the cirrhotic liver then either ascitic albumin is derived from the systemic circulation or a unique pathway for the transfer of hepatic albumin to ascites and lymph exists.

The availability of a method which will rapidly label newly made albumin $(5,6)$ provided an opportunity to investigate the sources of ascitic fluid albumin. The intravenous injection of albumin ${ }^{218} I$ was used as a measure of albumin transfer from plasma to ascites while the injection of carbonate- ${ }^{14} \mathrm{C}$ permitted assay of the newly formed albumin transferred into ascitic fluid. If more albumin $-{ }^{14} \mathrm{C}$ appeared in the ascitic fluid than could be accounted for by the transfer of albumin ${ }^{-181} \mathrm{I}$ from the plasma then some newly made albumin must be arriving in ascites by another route. The results of studies in eight patients obtained by assaying the plasma, thoracic duct lymph, and ascites for ${ }^{121} \mathrm{I}$ - and ${ }^{14} \mathrm{C}$-labeled albumin, demonstrated that more newly made albumin entered the ascitic fluid than could be explained by transfer from the systemic circulation.

Patients. All subjects were male patients, hospitalized at the Manhattan Veterans Administration Hospital. All subjects evidenced significant amounts of ascitic fluid and chemical evidence of severe hepatic dysfunction. All 
patients had a prolonged history of heavy alcoholic intake. The diet in the hospital consisted of $40 \mathrm{~g}$ of protein and was low in sodium and supplemented by vitamins. Diuretics were withheld for 2 days before study. Patients were studied after an overnight fast.

Protocol. All studies were initiated at 9 a.m. with the intravenous injection of 5-10 $\mu \mathrm{c}$ of albumin ${ }^{181} \mathrm{I}$ and $200 \mu \mathrm{c}$ of carbonate $-{ }^{14} \mathrm{C} .10 \mathrm{ml}$ of heparinized blood was drawn at $10 \mathrm{~min}$ for determinations of plasma volume. In three patients, $1000 \mathrm{ml}$ of ascitic fluid and $100 \mathrm{ml}$ of heparinized blood were obtained at the end of $1 \mathrm{hr}$. In all patients $10 \mathrm{ml}$ of ascitic fluid was obtained at $110 \mathrm{~min}$. Immediately thereafter, $5-10 \mu \mathrm{c}$ of albumin ${ }^{131} \mathrm{I}$ was injected directly into ascitic fluid and $10 \mathrm{~min}$ later, after rolling the patient from side to side, $500-1000 \mathrm{ml}$ of ascitic fluid were withdrawn over the next $10-15 \mathrm{~min}$. Simultaneously $100-150 \mathrm{ml}$ of heparinized blood was slowly withdrawn. The ascitic fluid was obtained in two fractions during the collection in five of the eight patients and both samples were assayed for albumin ${ }^{131} \mathrm{I}$.

In patients 7 and 8 , the thoracic duct was cannulated in the neck under local anesthesia and gravity drainage instituted before the injection of the isotopes. The thoracic duct lymph was collected during the $2 \mathrm{hr}$ procedure in $\frac{1}{2} \mathrm{hr}$ aliquots. The lymph was not returned to the patient.

\section{METHODS}

Albumin- ${ }^{131} I . \quad$ Albumin- ${ }^{131} I$ injected into the plasma served as an index for the transfer of plasma albumin into ascites. A mean plasma value between 10 and $120 \mathrm{~min}$ was used in all calculations. Since the plasma concentration of albumin${ }^{131} \mathrm{I}$ was falling slowly during the $2 \mathrm{hr}$ of the study this calculation did not introduce a significant error. Total plasma, ascitic, and lymphatic albumin-181 I activity was determined as the product of the measured volumes and the mean protein-181 ${ }^{131}$ precipitable activity per unit volume. The ratios of the total albumin $-{ }^{181} \mathrm{I}$ in ascites/plasma $(\mathrm{A} / \mathrm{P})$ and lymph/plasma (L/P) serves to measure the transfer of plasma albumin to ascites and to lymph.

Carbonate ${ }^{14} \mathrm{C}$. The carbonate ${ }^{14} \mathrm{C}$ by labeling the hepatic intracellular arginine pool is the immediate precursor of the guanido carbon in albumin. Albumin contains about $4.23 \mathrm{mg}$ of guanido carbon $/ 1.0 \mathrm{~g}$ of albumin (7). After intravenous injection, the plasma concentration of carbonate $-{ }^{14} \mathrm{C}$ falls rapidly reaching levels $5-15 \%$ of the initial plasma level between 90 and $120 \mathrm{~min}$ (8). Albumin $-{ }^{14} \mathrm{C}$ appears in the plasma after about $30 \mathrm{~min}$ in humans, rabbits, and in the perfusate in the isolated perfused liver $(6,9)$. Thereafter the concentration rises rapidly over the next $1.5-3.0 \mathrm{hr}$. It is during this period that the present studies were undertaken (6).

In all patients the total ascitic fluid guanido carbon in albumin obtained 1 or $2 \mathrm{hr}$ after carbonate- ${ }^{14} \mathrm{C}$ injection was compared with the total guanido carbon in plasma albumin at the same time period. The amount of ${ }^{14} \mathrm{C}$-labeled albumin in the plasma available for transfer from plasma to lymph or to ascites was always less than the amount used in our calculations due to the rapid rise in the plasma level during the $2 \mathrm{hr}$ study. Thus the use of these 1 - and 2 -hr plasma values to calculate the fraction of the plasma pool present in the ascites or lymph would always underestimate this fraction. Quantitation of the amount of unlabeled albumin transfered into ascites and plasma during the study was not possible due to the rapidly changing specific activities within the various compartments.

The 1-hr plasma albumin- ${ }^{11} \mathrm{C}$ guanido carbon content served as the basis for both the $\frac{1}{2}$ and $1 \mathrm{hr} \mathrm{L} / \mathrm{P}$ ratios and the $2 \mathrm{hr}$ plasma ${ }^{14} \mathrm{C}$ content for the $1 \frac{1}{2} \mathrm{hr}$ and $2 \mathrm{hr} \mathrm{L} / \mathrm{P}$ ${ }^{14} \mathrm{C}$ ratios. By comparing the ratios $\mathrm{A} / \mathrm{P}$ and $\mathrm{L} / \mathrm{P}$ for albumin- ${ }^{131} \mathrm{I}$ with the ratios $\mathrm{A} / \mathrm{P}$ and $\mathrm{L} / \mathrm{P}$ for albumin $-{ }^{14} \mathrm{C}$ guanido carbon present in the ascitic pool and lymph it was possible to determine if all the albumin transferred into these areas comes from the plasma. Total pool size of albumin guanido carbon was calculated from the product of pool volume albumin concentration and guanido carbon content of albumin.

The plasma volume was determined from the space of distribution of albumin-181 I at $10 \mathrm{~min}$. Ascitic fluid volume was determined from the space of distribution of the albumin- ${ }^{131} I$ injected directly into the ascitic fluid. The two samples of ascitic fluid contained essentially identical activity indicating adequate mixing within the ascitic volume as has been reported (10). There was negligible albumin ${ }^{131} \mathrm{I}$ activity in the ascitic fluid due to the previous plasma injection. Albumin- ${ }^{131} I$ was assayed in a well scintillation counter and the samples were checked for precipitability with trichloroacetic acid.

Albumin was isolated from the samples of blood, ascitic fluid, and lymph by precipitation in $5 \%$ trichloroacetic acid (TCA) as has been described (11). The precipitate was extracted with $95 \%$ ethanol-1\% TCA. Three parts of diethylether were added to the extract to reprecipitate the albumin; the albumin redissolved and dialyzed overnight. This procedure was repeated and a sample of the protein was concentrated to $6 \%$ and examined by immunoelectrophoresis (12) to guard against the use of a preparation which contained obvious serum protein contamination as has been described previously (11). The albumin was hydrolyzed with $6 \mathrm{~N} \mathrm{HCl}$, neutralized and passed through a resin column according to the method of McFarlane (6), and treated consecutively with arginase and urease. An aliquot was taken for nitrogen analysis by incubation with urease according to the method of Conway and Byrne $(11,13)$. Ammonia was released with $45 \% \quad \mathrm{~K}_{2} \mathrm{CO}_{3}$ trapped in $2 \mathrm{~N} \mathrm{H}_{2} \mathrm{SO}_{4}$, and assayed with a Nessler's reagent. An identical aliquot was incubated with urease and the ${ }^{14} \mathrm{CO}_{2}$ released with phosphoric acid was trapped in phenethylamine, dissolved in a scintillator, and assayed in a Nuclear-Chicago ambient temperature scintillation counter. (11). Total protein was determined with a biuret reagent (14) and protein partition with a Kern microelectrophoresis unit (15).

Hepatic function was evaluated in each patient by means of standard liver function tests (11).

\section{RESULTS}

The data obtained from the eight patient studies are shown in Table I. The ascitic fluid volume ranged from 1.25 to over 19 liters. The total radioactivity of albumin${ }^{14} \mathrm{C}$ in ascitic fluid at the end of $2 \mathrm{hr}$, expressed as a per cent of that present in the plasma at the same time, was much greater than the albumin ${ }^{181} I$, expressed as a per cent of the mean albumin- ${ }^{181}$ I present in the plasma, in seven of the eight patients studied. The $\mathrm{A} / \mathrm{P}$ ratio for albumin $-{ }^{121} \mathrm{I}$ was $0.4-2.2 \%$ and for albumin $-{ }^{14} \mathrm{C}$ the $\mathrm{A} / \mathrm{P}$ 
ratio was $4.0-11.7 \%$. Because of the rapid increase in the amount of albumin ${ }^{14} \mathrm{C}$ entering the plasma the absolute amount of albumin (labeled and unlabeled) entering ascitic fluid can not be calculated. If all the ascitic albumin was derived from the systemic circulation the $\mathrm{A} / \mathrm{P}$ ratios for albumin $-{ }^{131} \mathrm{I}$ and albumin $-{ }^{14} \mathrm{C}$ should be identical. Thus about $4.0-11.7 \%$ of the plasma albumin${ }^{131}$ I would have had to be transferred to account for all of the ascitic fluid ${ }^{14} \mathrm{C}$ activity. Since this was not the case some newly made albumin must have entered the ascitic fluid by another route than from the plasma.

In patient C.A.R. whose ascites was rapidly decreasing as evidenced by a $10 \mathrm{~kg}$ weight loss over 6 days and an ascites pool of only $2450 \mathrm{ml}$, the amount of albumin $-{ }^{14} \mathrm{C}$ in the ascites was small $(1.2 \%)$, although the $\mathrm{A} / \mathrm{P}$ ratio was still twice that of albumin ${ }^{-131} \mathrm{I}(0,6 \%)$. The net loss of albumin- ${ }^{131} \mathrm{I}$ from the circulation to all extraplasma sites including that which was removed by the blood taking, averaged $8.6 \pm 1.3 \%( \pm \mathrm{SE})$ in the eight subjects during the $2 \mathrm{hr}$ study.

The plasma volume was considerably elevated in seven of the eight patients. The serum albumin level was depressed to values between 1.3 and $2.6 \mathrm{~g} / 100 \mathrm{ml}$ whereas the albumin level in the ascitic fluid ranged from 0.1 to $1.4 \mathrm{~g} / 100 \mathrm{ml}$.

Lymphatic drainage in the two patients, R.E.I. and K.L.O., did not reduce the amount of albumin ${ }^{14} \mathrm{C}$ found in ascitic fluid (Table I). However, it was possible to show that more newly made albumin was transferred into the lymph than could be accounted for by plasma to lymph transfer. The fraction of plasma albumin $-{ }^{131} \mathrm{I}$ pool found in lymph after $2 \mathrm{hr}$ was $2.8-3.8 \%$ whereas for the newly synthesized albumin, it was 6.1 and $13.5 \%$. No albumin $-{ }^{14} \mathrm{C}$ appeared in lymph in the first $30 \mathrm{~min}$ (Table II).

Patient R.E.I. had an end-to-side portacaval shunt performed $2 \mathrm{yr}$ before this study and had ascites for 1 yr. Physiologic studies showed a functioning shunt with persistent hepatic sinusoidal hypertension (wedged hepatic vein pressure $30 \mathrm{~cm} \mathrm{H} \mathrm{H}_{2} \mathrm{O}$ ) and normal splanchnic pressure (splenic pulp pressure $17 \mathrm{~cm} \mathrm{H}_{2} \mathrm{O}$ ).

\section{DISCUSSION}

The use of the carbonate ${ }^{14} \mathrm{C}$ method has permitted the short-term study of hepatic albumin synthesis. This method described by Swick (5), Reeve, Pearson, and Martz (16), and McFarlane (6) is based upon the fact that intracellular arginine is the direct precursor of arginine in albumin. Approximately $2 \%$ of the injected carbonate enters the arginine-urea cycle and also labels the guanido carbon of arginine in albumin (6). Albumin begins to be released from the liver after about $0.5 \mathrm{hr}$ and reaches a maximum specific activity $2.5-3 \mathrm{hr}$ after a single injection of carbonate $-{ }^{14} \mathrm{C}(6,8,17,18)$. Thus,

TABLE I

Albumin Transfer in Patients with Cirrhosis and Ascites

\begin{tabular}{|c|c|c|c|c|c|c|c|c|c|c|c|c|}
\hline & \multirow[b]{2}{*}{ Patient } & \multirow{3}{*}{$\frac{\begin{array}{c}\text { Time } \\
\text { of } \\
\text { study }\end{array}}{\min }$} & \multirow{3}{*}{$\begin{array}{c}\begin{array}{c}\text { Ascites } \\
\text { volume }\end{array} \\
m l\end{array}$} & \multirow{3}{*}{$\begin{array}{c}\text { Net al- } \\
\text { bumin- } \\
{ }^{14} \mathrm{C} \text { to } \\
\text { ascites } \\
\text { plasma } \\
\text { pool, } \\
\text { A/P } \\
\%\end{array}$} & \multirow{3}{*}{$\begin{array}{c}\text { Net al- } \\
\text { bumin- } \\
\text { 1s1 to } \\
\text { ascites } \\
\text { plasma } \\
\text { pool, } \\
\text { A/P }\end{array}$} & \multirow{3}{*}{$\begin{array}{c}\begin{array}{c}\text { Net } \\
\text { plasma } \\
\text { albumin- } \\
181 \text { I } \\
\text { loss }\end{array} \\
\%\end{array}$} & \multirow{2}{*}{\multicolumn{2}{|c|}{ Plasma volume }} & \multicolumn{2}{|c|}{ Plasma } & \multicolumn{2}{|c|}{ Ascites } \\
\hline & & & & & & & & & $\begin{array}{l}\text { Pro- } \\
\text { tein }\end{array}$ & $\begin{array}{c}\text { Albu- } \\
\text { min }\end{array}$ & $\begin{array}{l}\text { Pro- } \\
\text { tein }\end{array}$ & $\begin{array}{c}\text { Albu- } \\
\text { min }\end{array}$ \\
\hline & & & & & & & $m l$ & $\mathrm{ml} / \mathrm{kg}$ & \multicolumn{2}{|c|}{$\mathrm{g} / 100 \mathrm{ml}$} & \multicolumn{2}{|c|}{$\mathrm{g} / 100 \mathrm{ml}$} \\
\hline 1 & O. P. E. & 120 & 1250 & 4.0 & 0.5 & 6.8 & 3520 & 53.5 & 7.1 & 1.3 & 1.9 & 0.6 \\
\hline 2 & H. A. W. & 120 & 1300 & 4.2 & $\cdot 0.4$ & 3.5 & 5200 & 60.8 & 4.7 & 1.3 & 0.3 & 0.1 \\
\hline 3 & C. A. R. & 120 & 2450 & 1.2 & 0.6 & 15.6 & 3970 & 56.0 & 6.6 & 2.6 & 2.1 & 0.9 \\
\hline 4 & M. O. C. & 120 & 4150 & 7.0 & 1.1 & 12.0 & 5025 & 65.8 & 6.3 & 2.5 & 2.9 & 1.4 \\
\hline 5 & F. E. Y. & 120 & 9200 & 11.7 & 0.7 & 8.6 & 3500 & 56.5 & 6.8 & 2.3 & 2.1 & 0.7 \\
\hline \multirow[t]{2}{*}{6} & M. C. N. & 60 & 12,500 & 6.1 & 2.0 & & 3270 & 54.0 & 5.9 & 2.2 & 1.5 & 0.5 \\
\hline & & 120 & & 7.9 & 2.2 & 2.7 & & & & & & \\
\hline \multirow[t]{2}{*}{7} & R. E. I.* $\ddagger$ & 60 & 12,800 & 16.5 & 1.1 & & 4350 & 51.9 & 6.8 & 1.8 & 3.2 & 1.1 \\
\hline & & 120 & & 7.0 & 1.6 & 11.7 & & & & & & \\
\hline \multirow[t]{4}{*}{8} & K. L. O.* & 60 & 19,700 & 17.1 & 0.9 & & 3680 & 44.0 & 6.4 & 1.8 & 1.9 & 0.7 \\
\hline & & 120 & & 6.2 & 1.6 & 7.8 & & & & & & \\
\hline & $2 \mathrm{hr}$ mean & & & 6.2 & 0.9 & 8.6 & & & & & & \\
\hline & $\pm \mathrm{SEM}$ & & & 0.9 & 0.2 & 1.3 & & & & & & \\
\hline
\end{tabular}

* Thoracic duct cannulated and lymph collected.

$\ddagger$ Patient R. E. I. had a functioning end-to-side portacaval shunt performed, 1966. Ascites developed in 1967. 
TABLE II

Lymph Studies

\begin{tabular}{|c|c|c|c|c|c|c|c|c|}
\hline \multirow[b]{2}{*}{ Patient } & \multirow[b]{2}{*}{ Time } & \multirow[b]{2}{*}{$\begin{array}{l}\text { Lymph } \\
\text { volume }\end{array}$} & \multicolumn{2}{|c|}{$\begin{array}{l}\text { Cumulative per cent } \\
\text { of total plasma ra- } \\
\text { dioactivity appear- } \\
\text { ing in lymph, } \mathrm{L} / \mathrm{P}\end{array}$} & \multirow{2}{*}{$\begin{array}{l}\text { Total al- } \\
\text { bumin-14C, } \\
2 \mathrm{hr} \text {, lymph/ } \\
\text { ascites }\end{array}$} & \multicolumn{3}{|c|}{ Albumin } \\
\hline & & & $\begin{array}{l}\text { Albumin- } \\
{ }_{131} \text { I }\end{array}$ & $\underset{{ }_{14} \mathrm{C}}{\text { Albumin- }}$ & & Lymph & Ascites & Plasma \\
\hline \multirow{5}{*}{ R. E. I. } & $\min$ & $m l$ & $\%$ & $\%$ & & & $\mathrm{~g} / 100 \mathrm{ml}$ & \\
\hline & $0-30$ & 137 & 0.4 & 0 & & & & \\
\hline & $30-60$ & 104 & 1.3 & 1.2 & & & & \\
\hline & $60-90$ & 103 & 2.2 & 3.4 & & & & \\
\hline & $90-120$ & .136 & 3.8 & 6.1 & 0.55 & 0.9 & 1.1 & 1.8 \\
\hline \multirow[t]{3}{*}{ K. L. O. } & $0-30$ & 80 & 0.5 & 0 & & & & \\
\hline & $30-60$ & 93 & 1.5 & 7.4 & & & & \\
\hline & $60-120$ & 123 & 2.8 & 13.5 & 0.89 & 1.1 & 0.7 & 1.8 \\
\hline
\end{tabular}

an opportunity to study the route of the released newly formed albumin occurs during this period of time.

The results of the present study indicate that all of the albumin moving into ascitic fluid in patients with ascites could not have been derived from the systemic circulation for the amount of newly formed albumin in ascitic fluid was 4-17 times greater than that accounted for by the transfer of albumin $-{ }^{131} \mathrm{I}$ which was injected directly into the plasma. There was a mean loss of $8-9 \%$ of albumin ${ }^{131}$ I from the plasma to all extraplasma sites during this short study and the use of the smallest albumin- ${ }^{181} \mathrm{I}$ plasma pool to calculate the $A / P$ ratio for albumin ${ }^{131} \mathrm{I}$ would not influence the results significantly. The delayed release and changing specific activity of albumin $-{ }^{14} \mathrm{C}$ necessitate the use of the 1- and 2-hr plasma pools of albumin $-{ }^{14} \mathrm{C}$ to calculate the albumin- ${ }^{14} \mathrm{C} A / P$ and $L / P$ ratios. Since the albumin $-{ }^{14} \mathrm{C}$ pool in the plasma was increasing rapidly during these times the use of these single points resulted in the minimum values for the ${ }^{14} \mathrm{C} \mathrm{A} / \mathrm{P}$ ratio.

In two cases this ascitic to plasma albumin $-{ }^{14} \mathrm{C}$ ratio decreased from 16.5 and $17.1 \%$ after $1 \mathrm{hr}$ to 6 and $7 \%$ respectively after $2 \mathrm{hr}$. These high $1 \mathrm{hr} A / \mathrm{P}{ }^{14} \mathrm{C}$ ratios were seen at a time when the rate of increase in total plasma albumin $-{ }^{14} \mathrm{C}$ is most rapid, during the first hour when the specific activity of the precursor pool is highest (8). If the amount of newly made albumin that moved directly into ascitic fluid was simply a small fraction of that entering the plasma at all times, this $A / P$ ratio should be constant. The decrease in the $A / P$ ratio with time suggests that the transfer of albumin $-{ }^{14} \mathrm{C}$ into ascites may have taken a shorter pathway than the albumin $-{ }^{14} \mathrm{C}$ entering the plasma. Thus some albumin $-{ }^{14} \mathrm{C}$ would begin to accumulate in ascites in these two patients with thoracic duct cannulation before appearing in the plasma. The transfer of newly made albumin from the source of assembly to its plasma appearance is about $30 \mathrm{~min}$ and the absence of ${ }^{14} \mathrm{C}$ activity in lymph before 30 min supports this observation (6). Where the delay occurs from the endoplasmic reticulum to sinusoidal appearance is not clear. The presence of a functioning portacaval shunt in patient R.E.I. did not inhibit this transfer of albumin into the ascitic compartment.

The early appearance of the albumin $-{ }^{14} \mathrm{C}$ in ascites would result in a labeled albumin derived from an arginine pool of higher specific activity initially. However, by $2 \mathrm{hr}$, over $80-85 \%$ of the $\mathrm{CO}_{2}{ }^{14} \mathrm{C}$ is removed from the plasma (7) and thus the albumin released from the liver at this time would be of low specific activity, and the opportunity to determine modes of transfer of newly made albumin would be minimized.

The loss of albumin from the plasma to all extravascular sites during the $110 \mathrm{~min}$ would have affected the calculation of the plasma to the ascitic transfer of both labeled albumins, more so with albumin ${ }^{131} \mathrm{I}$ since it was in the plasma longer. Wooley and Coutrice (3) and more recently Smallwood and associates (4) have demonstrated that newly formed albumin enters the plasma which in turn equilibrates with the lymph. In dogs with hepatic venous obstruction the albumin in the lymph could still be accounted for as having come from the plasma (4). However, in the two patients who. were studied during thoracic duct drainage there was more new albumin in the lymph than albumin ${ }^{131} \mathrm{I}$ and thus some direct transfer from the hepatocyte into lymph must have occurred in these cirrhotic patients with ascites.

These observations do not permit elucidation of the specific pathway by which albumin enters ascitic fluid. Direct lymphatic drainage into ascites or direct loss through the capsule could occur. However, if the interstitial space is the immediate depository for newly synthesized albumin, then in cirrhosis this space must 
have access to lymph and ascitic fluid before equilibration with plasma.

Hepatic production of albumin may be normal or increased in patients with cirrhosis and ascites (11) and the loss of a fraction of the productive capacity directly into ascitic fluid could be significant. The observation that no significant loss by this unique route was observed in one patient whose ascites was decreasing suggests that this is a reversible process. The findings do demonstrate that the formation of ascites is complicated by a direct transfer of newly synthesized albumin into the peritoneal cavity from the liver by a unique and probably short route, bypassing the systemic circulation. This route may be an important factor in ascitic fluid accumulation.

\section{ACKNOWLEDGMENTS}

The authors wish to acknowledge the secretarial assistance of Miss Judith Rosenblum.

This work was supported in part by U. S. Public Health Service Grant AM 02489.

\section{REFERENCES}

1. Cherrick, G. R., D. N. S. Kerr, A. E. Read, and S Sherlock. 1960. Colloid osmotic pressure and hydrostatic pressure relationships in the formation of ascites in hepatic cirrhosis. Clin. Sci. 19: 361.

2. Miller, L. L., C. G. Bly, M. L. Watson, and W. F. Bale. 1951. The dominant role of the liver in plasma protein synthesis. A direct study of the isolated perfused rat liver with the aid of lysine-E-C ${ }^{14}$. J. Exp. Med. 94: 431 .

3. Woolley, G., and F. C. Courtice. 1962. The origin of albumin in hepatic lymph. Aust. J. Exp. Biol. Med. Sci. 40: 121 .

4. Smallwood, R. A., E. A. Jones, A. Craigie, S. Raia, and V. M. Rosenoer. 1968. The delivery of newly synthesized albumin and fibrinogen to the plasma in dogs. Clin. Sci. 35 : 35.

5. Swick, R. W. 1958. Measurement of protein turnover in rat liver. J. Biol. Chem. 231: 751.

6. McFarlane, A. S. 1963. Measurement of synthesis rates of liver produced plasma protein. Biochem. J. 89: 277.
7. Tristram, G. R., and R. H. Smith. 1963. The amino acid composition of some purified proteins. In Advances in Protein Chemistry. C. B. Anfinsen, M. L. Anson, K. Bailey, and J. Edsall, editors. Academic Press Inc., New York. 18: 276.

8. Jones, E. A., A. Craigie, A. S. Tavill, W. Simon, and V. M. Rosenoer. 1968. Urea kinetics and the direct measurement of the synthetic rate of albumin utilizing $\left[{ }^{14} \mathrm{C}\right]$ carbonate. Clin. Sci. 35: 353.

9. Rothschild, M. A., M. Oratz, J. Mongelli, and S. S. Schreiber. 1968. Effects of a short term fast on albumin synthesis studied in vivo, in the perfused liver, and on amino acid incorporation by hepatic microsomes. J. Clin. Invest. 47: 2591 .

10. Berson, S. A., and R. S. Yalow. 1954. The distribution of $\mathrm{I}^{181}$-labeled human serum albumin introduced into ascitic fluid. Analysis of the kinetics of a three compartment catenary transfer system in man and speculations on possible sites of degradation. J. Clin. Invest. 33: 377.

11. Rothschild, M. A., M. Oratz, D. Zimmon, S. S. Schreiber, I. Weiner, and A. VanCaneghem. 1969. Albumin synthesis in cirrhotic subjects with ascites studied with carbonate- ${ }^{14} \mathrm{C}$. J. Clin. Invest. 48: 344.

12. Scheidegger, J. J. 1955 . Une micro-méthode de l'immunoélectrophorèse. Int. Arch. Allergy Appl. Immunol. 7: 103.

13. Conway, E. J., and A. Byrne. 1933. Absorption apparatus for microdetermination of certain volatile substances. Microdetermination of ammonia. Biochem. J. 27: 419 .

14. Gornall, A. G., C. J. Bardawell, and M. M. David. 1949. Determination of serum protein by means of the biuret reaction. J. Biol. Chem. 177: 751.

15. Rothschild, M. A., S. S. Schreiber, M. Oratz, and H. L. McGee. 1958. The effects of adrenocortical hormones on albumin metabolism studied with albumin $\mathrm{I}^{182}$. J. Clin. Invest. 37: 1229.

16. Reeve, E. B., J. B. Pearson, and D. C. Martz. 1963. Plasma protein synthesis in the liver. Method for measurement of albumin formation in vivo. Science (Washington). 13: 914.

17. Koj, A., and A. S. McFarlane. 1968. Effect of endotoxin on plasma albumin and fibrinogen synthesis rates in rabbits as measured by the $\left[{ }^{14} \mathrm{C}\right]$ carbonate method. Biochem. J. 108: 137.

18. Tavill, A. S., Craigie, A., and V. M. Rosenoer. 1967. The measurement of the synthetic rate of albumin in man. Clin. Sci. 34: 1 . 